\title{
THE ROLE OF THE LOCAL GOVERNMENT IN PROTECTION FROM NATURAL DISASTERS AND OTHER FORMS OF HAZARDS IN SERBIA
}

UDC 34:005.334:504.4(497.11)

\author{
Marijola Božović ${ }^{1}$, Snežana Živković \\ ${ }^{1}$ Higher Technical Professional School in Zvečan, Serbia \\ ${ }^{2}$ Faculty of Occupational Safety in Niš, University of Niš, Serbia
}

\begin{abstract}
The process of emergency management, starting from risk assessment of natural disasters and other hazards, through taking measures of prevention, protection and rescue, mitigation and restoration, should not be seen as burden on society, but rather as a factor of development. The dangers and accidents do not only take human lives, but inflict enormous, often irreparable damage that weakens the material power of the state and individuals, and can cause long-term problems to whole society. In that context, it is essential that the state influences the reduction of risks and dangers, increases the importance of participation and effectiveness of resources and capacities engaged in the process of emergency management, and thus, at the same time contributes to the security and development of whole society.

The paper deals with the problems related to the development of vulnerability assessment from natural disasters as one of the tasks of the local government in the emergency management. After the risks at the local community have been assessed, it is possible to have an insight into the available technical and human capacity in the local community and, based on the given situation and in accordance with the law, make protection and rescue plans.
\end{abstract}

Key words: natural disaster, risk, vulnerability assessment, risk assessment, local government

\section{INTRODUCTION}

The increase in population and the increasing demographic transition from rural to urban areas has enlarged a number of sources of harmful events caused by the human factor. Also, climate changes have caused an increased dynamics and intensity of adverse events whose

Received March 22, 2017 / Accepted May 12, 2017

Corresponding author: Snežana Živković

University of Niš, Faculty of Occupational Safety in Niš, Čarnojevića 10a, 18000 Niš, Serbia

E-mail: snezana.zivkovic@znrfak.ni.ac.rs 
sources are, at first glance, processes and events in nature, although indirectly it can be the result of human activities. Technological development has influenced the improvement of a large number of instruments for hazard identification. As Smith and Petley states, there is an obvious paradox between human progress and the constant feeling of insecurity [8].

The term hazard is a potentially damaging physical occurrence, a phenomenon, a substance or human activity that may cause loss of life or injury, damage to material goods, the interruption of social or economic activity or ecological degradation [11]. In that context, it is essential that the state influences the reduction of risks and dangers, increases the importance of participation and effectiveness of resources and capacities engaged in the process of emergency management, and thus, at the same time contributes to the security and development of the whole society. Regarding the issue of adequate emergency management at the local level, one must first do a thorough vulnerability assessment of the various forms of accidents and then, based on the level of risk at the local community, should look at what kind of available technical and human capacity the local community has at its disposal and based on the factual situation and in accordance with the law, make protection and rescue plans.

By creating risk assessment, all subjects mark their critical infrastructure. Conditions are created for forming forces for protection and rescue as well as equipping them with necessary resources. By fulfilling these basic assumptions, the subjects of protection and rescue system, and above all, local governments, companies and citizens provide their own protection and emergency response. Forces and means for protection and rescue should exist at the level of local government and of the Republic, and are activated as required in the case of emergencies [6]. Developed and harmonized risk assessment in all subjects of protection and rescue system creates an optimal environment for planned and organized training and training staffs and individuals, operational bodies and trained and authorized legal entities. Conformance of vulnerability assessment results in compatible plans for protection and rescue. Compatible plans for protection and rescue imply that there is no possibility of an accident occurring without some mechanism responding to it. The result of such state is an organized system of protection and rescue, in which every individual, operational body and headquarters knows their jurisdictions and obligations [6].

\section{INTERNATIONAL INITIATIVES}

The region of Southeast Europe is increasingly threatened by various types of natural hazards, some of which occur suddenly, unexpectedly and are life-threatening. They come in different shapes and sizes. Over the years, the European Union (EU) has built a number of capacities in order to coordinate the member states' response to natural disasters and foreign crises [1]. Through a completely new Emergency Response Centre which is engaged in activities in raising awareness among people about the significance of how every moment is important for rescuing human lives as well as field exercises in simulated emergency situations. All further actions and communications are controlled by Rescue Coordination Centre - RCC), which operates within the European Commission's Humanitarian Aid and Civil Protection Department - ECHO. ECHO coordinates joint assistance in disasters, both in member states and in other countries that are affected by disasters [3]. The EU supports the countries outside the EU through various civil-military missions [9]. National governments cannot deal with these crises unilaterally, nor can they 
isolate themselves from these threats. The world, especially Europe is becoming too connected and intertwined to avoid the reach of any crisis.

The Republic of Serbia is making significant efforts regarding the participation and cooperation with international organizations in the area of safety in emergency situations and bilateral cooperation with neighboring countries. The Sector for emergency situations of the Republic of Serbia participates in the activities of international institutions and organizations such as: United Nations International Strategy for Disaster Risk Reduction (UNISDR), Partial Agreement of the Council of Europe's EUR-OPA, Disaster Preparedness and Prevention Initiative (DPPI) for Southeastern Europe, United Nations Development Program (UNDP), Economic Commission for Europe - UNECE, UN Office for the Coordination of Humanitarian Affairs (UN - OCHA), Civil-military emergency planning (CMEP), Partnership for Peace within NATO, USAID, OSCE, the BSEC -Black Sea Economic Cooperation, Balkan Fire-fighting Sport Federation (BFSF) and others.

The Government of the Republic of Serbia is actively participating in the activities of international governmental and regional organizations that are engaged in the management of emergency situations and disaster risk reduction and accepts joint readiness for action that stems from such arrangements. In January 2005, Serbia, as many members of the United Nations, affirmed its determination to continue activities in order to reduce the risk of disasters by adopting Hyogo framework for action 2005-2015 [10] and the UN Action Plan for improving disaster preparedness of states and communities, adopted the same year on the World Conference on the disaster risk reduction in Japan.

\section{EMERGENCY MANAGEMENT AND VULNERBILITY ASSESSMENT AT THE LOCAL LEVEL}

By adopting the Law on emergency situations [5] and the Regulation on the content and the method of preparing plans for protection and rescue in emergency situations [7] as the base of the prescribed Guidelines on the Methodology for the preparation of vulnerability assessment of natural and other disasters and plans for protection and rescue in emergency situations [2] a new phase in the development of a methodology for assessing vulnerability to natural disasters and other disasters at all levels in the Republic of Serbia has begun

In accordance with the Law on emergency situations, there is an obligation on all levels from the local to national, to primarily do an adequate assessment of the vulnerability of the territory, depending on the dangers that threaten these territories. Also it is necessary to make risk assessment and plans for protection and rescue in emergency situations, which is also an obligation for business companies. The adoption of a number of by-laws should allow easier operation to all economic entities, so that they can make prompt and proper vulnerability assessment and protection and rescue plans, which should be implemented and applied in emergencies. When it comes to vulnerability assessment of a company or other legal person, it must be, first of all, taken into account the position and characteristics of the site, assessment of critical infrastructure from the point of vulnerability, identification of danger from natural and other disasters, as well as assessment of forces, resources and prevention measures for protection and rescue. It is very important that the risk assessment is made by a person with the license for risk assessment, issued by the Ministry of Internal Affairs to a person who had passed the professional exam. Kesetovic notes the significance of plans to educate personnel to make an assessment at the level of Sector and other subjects of the system [4]. Obligors that make Assessment of vulnerability and plans for protection 
and rescue in emergency situations are: state administration bodies, autonomous province bodies, the units of local governments, companies and other legal entities.

Assessment of vulnerability from natural disasters and other disasters is a basic document for drafting up a Plan for protection and rescue in emergency situations of units of local governments. Assessment is a document that identifies hazards, sources and forms of threats, possible effects and consequences, assessment of vulnerability-risks, assessment of forces, resources and preventive measures to address threats caused by natural disasters and other disasters, protecting and saving lives and health of people, animals, protection of material, cultural goods and the environment. Assessment is made on the basis of the Guidelines on the Methodology for the preparation of vulnerability assessment of natural and other disasters and plans for protection and rescue in emergency situations [2].

The plan is developed in accordance with the Regulation on the content and the method of preparing plans for protection and rescue in emergency situations. All subjects are obliged to draw up plans defined by the Law on emergency situations and the Regulation. The plan is used for planning operational measures, subjects, forces and resources that are used for protection and rescue of life and health of people, animals, material and cultural goods and environment against natural disasters and other disasters.

\section{THE METHOdOlogy FOR VULNERABILITY ASSESSMENT}

Methodology regulates the way of making a vulnerability Assessment of natural and other disasters [2]. The purpose of the methodology is to determine unique criteria for making the Assessment, increasing the quality and comparability of data and improving the database on the risks from natural and other disasters on the territory of the Republic of Serbia, autonomous province, units of local self-government, authorized and trained legal persons and other entities in accordance with the Law.

Vulnerability assessment identifies the sources of potential threat, seeing the possible consequences, needs and possibilities of implementation of measures and tasks for protection and rescue from natural and other disasters. Risk management involves the following phases: communication and consultation; determination of the context of the risk assessment (diagnosis, analysis and evaluation of risk); treatment of the risk and monitoring and revision.

Risk assessment determines the nature and degree of risk of potential hazards, vulnerability conditions and the consequences that could potentially endanger the lives and health of people, material goods and the environment. This is a process that involves determination (identification), analysis and evaluation of the risk. Evaluation contains the description of scenarios for each danger, then the context in which the scenarios are discussed, the results of the estimates of the risk and level of the risk (risk matrix) and a cartographic representation of all risks. In the end, the risk is evaluated by comparing the results of the risk analysis, so we get a clear picture of whether the risk will be acceptable or whether the adequate measures will be taken to lessen it.

Determination of the risk (risk identification) is the process of finding, recognizing and describing the risk. This phase in making the Assessment is realized by considering all scenarios as well as by defining what kind of risks exist, where they may occur, why they are occurring and whether they can cause consequences for the protected values.

Risk analysis is the process of understanding the nature of the risk and determining the level of the risk. The analysis is performed after the identification of risks in order to determine the probability and consequences for the protected values. 
Risk evaluation is the process of comparing the result of the risk analysis with risk criteria, in order to determine whether the risk or the size of it can be tolerated.

Risk handling (risk treatment) is the process which is carried out to modify - reduce the risk. In this regard, the necessary analysis of taking measures is performed to reduce or eliminate the risks which may endanger or leave certain consequences on the protected values, as well as the need for building the capacities for the response.

Vulnerability assessment at national, provincial and at the level of the local government unit consists of a general and special section. The general section is related to the position and characteristic of the territory for which the assessment is made, as well as to the identification of the critical infrastructures of particular importance at the level of the local self-government.

\subsection{Special section}

1. Identification of the danger from natural disasters and other disasters

Identification of the danger is carried out on the entire territory which is the part of the vulnerability Assessment. By identifying the danger, parts of the territory which are vulnerable to a threat are defined. On the map of the territory, some risks are displayed-dangers and parts of the territory which are more or less at risk from these dangers. Based on the identified dangers, possible developments are determined - accident scenario, the intensity and analysis of the consequences according to dangers. Of the identified dangers, the selection is made of only those dangers characteristic for a specific territory, and they represent input elements for making assessment in accordance with the following parameters: earthquakes, landslides, erosion, floods, extreme weather conditions (the lack of drinking water), epidemics and pandemics, plant diseases, animal diseases, fires and explosions, wildfires, technicaltechnological accidents, nuclear and radiological accidents, the threat of a terrorist attack.

2. Guidelines for the development of scenarios

Scenario represents a description of the following:

1) Adverse events (one or more connected events of different nature) for each danger, and that has consequences on human life and health, economy/ecology, social stability;

2) Everything which leads to the occurrence of, i.e. cause adverse events described above, and consists of all the actions and events before and after the occurrence of the adverse event;

3) The circumstances in which adverse events occur, the degree of vulnerability and resilience of the population, buildings and other contents in the area or society on a scale relevant to consider the implications of the events for human life and health, as well as the environment, property, economy/ecology and social stability;

4) The result of the adverse events with a detailed description of every consequence.

Scenario is made for two types of events, including:

1) The most likely adverse event (an event which is known to appear often, that conditions in which the result appears in its emergence, and it is realistic to expect that it can, in certain area, endanger human lives and health and do material damage);

2) Adverse event with the most severe consequences possible (rare event that occurs in a particular area, and in the case of its appearance it has such intensity which consequences can be catastrophic for the all of the protected values). 
Scenario must meet the following requirements:

1) To be probable, supported by the facts, i.e. to describe the adverse events within the danger that can really occur;

2) To describe the consequences of adverse events within a particular danger, which have an influence on at least two protected values (Table 2);

3) To be constructed consistently, and may vary in weight and in the range from the real to the worst event according to the severity of the consequences;

4) To be set at the time and conditions that correspond to the actual situation;

5) To describe the possible events in such detail as necessary, so that based on scenario, the realistic treatment of the risk could be enforced (risk treatment);

6) To take into account the existing legislative framework, as well as the necessary changes for the purpose of reducing the risk;

7) To take into account the condition and capacity of the protection and rescue system (early warning system, operational forces, the ability of subjects of special importance for protection and rescue, etc.).

Prerequisites for the selection of scenarios are:

1) The probability of the event and

2) The amount/severity of the consequences.

Mandatory content of the scenario is shown in Table 1.

Table 1 Content of the scenario

\begin{tabular}{|c|c|}
\hline Parameter & General issues \\
\hline Work group & $\begin{array}{l}\text { - Name of the danger } \\
\text { - The composition of the working group }\end{array}$ \\
\hline Danger & - Description of the danger \\
\hline Occurrence & - The event site \\
\hline Spatial dimension & - The affected area \\
\hline Intensity & - The intensity of the event \\
\hline Time & $\begin{array}{l}\text { - The time of occurrence? (time of day, day, month and year) } \\
\text { - Cause if it is known }\end{array}$ \\
\hline Course & - Timeline of event and what it includes \\
\hline Duration & - Duration and a direct impact on the protected values \\
\hline Early announcement & - Whether the event is expected? \\
\hline Preparedness & $\begin{array}{l}\text { - Is the population prepared? } \\
\text { - Are the state authorities prepared for the response? }\end{array}$ \\
\hline Influence & $\begin{array}{l}\text { - What protected values were affected and what were the consequences? } \\
\text { - Number of the vulnerable population in the affected area } \\
\text { - Impact on the critical infrastructure }\end{array}$ \\
\hline Generation of other dangers & - Multi risk \\
\hline Reference incidents & $\begin{array}{l}\text { - Was there similar event in the past and when? } \\
\text { (probability and consequences) }\end{array}$ \\
\hline Informing the public & - Is there timely and accurate informing of the public? \\
\hline Future information & - What else is important for a scenario and that has not been included? \\
\hline
\end{tabular}


3. Guidelines for the development of an assessment

3.1. Protected Values

Assessment is a collection of risk assessments expressed in the scenarios based on dangers that may cause consequences on the territory or a part of the territory of the Republic of Serbia. Assessment can identify sources of potential threat, view the possible consequences, needs and possibilities of implementation of measures and tasks of protection and rescue from natural and other disasters in relation to protected values of society (Table 2). Assessment defines the value of the influence of all dangers separately for each of the following protected values:

- People's life and health;

- Economy/Ecology;

- Social stability.

Table 2 Protected values

\begin{tabular}{ll}
\hline Protected values & Criteria \\
\hline People's life and health & $\begin{array}{l}\text { The total number of people affected by some process (dead, injured, } \\
\text { sick, evacuated, displaced - homeless, provided and sheltered) }\end{array}$ \\
$\begin{array}{l}\text { Economy/ecology } \\
\text { Social stability }\end{array}$ & $\begin{array}{l}\text { 1. Total material damage to buildings and infrastructure of special } \\
\text { importance (critical infrastructure) }\end{array}$ \\
$\begin{array}{l}\text { 2. Total material damage to facilities/buildings of special public } \\
\text { importance }\end{array}$ \\
\hline
\end{tabular}

3.2. Assessment of probability

There are three different approaches to assessing the probability of the event:

a) Expert evaluation (Qualitative);

b) Prediction probability (Probability);

c) Use of data about past events (Frequency).

Probability refers to the event with damaging consequence.

Table 3 Table for expressing the probability

\begin{tabular}{clcll}
\hline \multirow{2}{*}{ Category } & \multicolumn{3}{c}{ Probability or frequency } & Selected \\
\cline { 2 - 5 } & (a) Qualitative & (b) Probability & Frequency & \\
2 & Negligible & $<1 \%$ & 1 event in 100 years or less & \\
3 & Small & $1-5 \%$ & 1 event in 20-100 years & \\
4 & Ledium & $6-50 \%$ & 1 event in 2-20 years & \\
5 & Extremely large & $51-98 \%$ & 1 event in 1-20 years & \\
\hline
\end{tabular}

3.3. Assessment of the consequences

The consequences represent the effect of adverse event to the life and health of people, to economy/ecology and social stability, and it is manifested through the size of the loss (damage). 
Table 4 Table for expressing the consequences to the life and health of people

\begin{tabular}{clcc}
\hline \multirow{2}{*}{ Category } & \multicolumn{3}{c}{ Consequences to the life and health of people } \\
\cline { 2 - 4 } & Size of the consequences & Criteria & Selected \\
\hline 1 & Minimum & $<50$ & \\
2 & Small & $50-200$ & \\
3 & Moderate & $201-500$ & \\
4 & Serious & $501-1,500$ & \\
5 & Catastrophic & $>1,500$ & \\
\hline
\end{tabular}

Table 5 Table for expressing the consequences to the economy/ecology

\begin{tabular}{clll}
\hline \multirow{2}{*}{ Category } & \multicolumn{3}{c}{ Consequences to the economy/ecology } \\
\cline { 2 - 4 } & $\begin{array}{l}\text { Size of the } \\
\text { consequences }\end{array}$ & Criteria & Selected \\
\hline 1 & Minimum & Which amount exceeds 1\% of the budget & \\
2 & Small & Which amount exceeds $3 \%$ of the budget & \\
3 & Moderate & Which amount exceeds $5 \%$ of the budget & \\
4 & Serious & Which amount exceeds $10 \%$ of the budget & \\
5 & Catastrophic & Which amount exceeds 15\% of the budget & \\
\hline
\end{tabular}

Table 6 Table for expressing the consequences to social stability - the total damage to critical infrastructure

\begin{tabular}{clrl}
\hline \multirow{2}{*}{ Category } & \multicolumn{2}{c}{ Consequences to social stability - the total damage to critical infrastructure } \\
\cline { 2 - 4 } & Size of the consequences & Criteria & Selected \\
\hline 1 & Minimum & $<1 \%$ of the budget \\
2 & Small & $1-3 \%$ of the budget \\
3 & Moderate & $3-5 \%$ of the budget \\
4 & Serious & $5-10 \%$ of the budget \\
5 & Catastrophic & $>10 \%$ of the budget & \\
\hline
\end{tabular}

Table 7 Table for expressing the consequences to social stability - the total damage to facilities/buildings of special public importance

\begin{tabular}{clcc}
\hline \multirow{2}{*}{ Category } & \multicolumn{2}{c}{$\begin{array}{c}\text { Consequences to social stability }- \text { the total damage to facilities/buildings } \\
\text { of special public importance }\end{array}$} \\
\cline { 2 - 4 } & Size of the consequences & Criteria & Selected \\
\hline 1 & Minimum & $<0.5 \%$ of the budget & \\
2 & Small & $0.5-1 \%$ of the budget & \\
3 & Moderate & $1-3 \%$ of the budget & \\
4 & Serious & $3-5 \%$ of the budget & \\
5 & Catastrophic & $>5 \%$ of the budget & \\
\hline
\end{tabular}

3.4. The level of the risk

At this stage, what is a very high, high, moderate or low risk is to be decided. 
Table 8 Levels and acceptability of the risk

\begin{tabular}{lc}
\hline Very high (red) & Unacceptable \\
High (orange) & Unacceptable \\
Moderate (yellow) & Acceptable \\
Low (green) & Acceptable \\
\hline
\end{tabular}

The purpose of risk evaluation is to prepare a basis for making decisions about the importance of certain risks, i.e. whether to accept or to take certain measures to lessen the risk. After the analysis of the risk (understanding the nature of the risk and determination of the level of the risk), the evaluation of the risk is being performed.

\subsection{Creating a matrix}

The results of the scenario (probability and consequences) are combined into a risk matrix. Risk matrix is consisted of two axis, axis of consequences and axis of probabilities. Each axis has five levels, which provides a matrix of 25 fields. The above mentioned 25 of those fields are divided into four risk categories: low, moderate, high and very high risk.

Matrix 1 The risk to human life and health

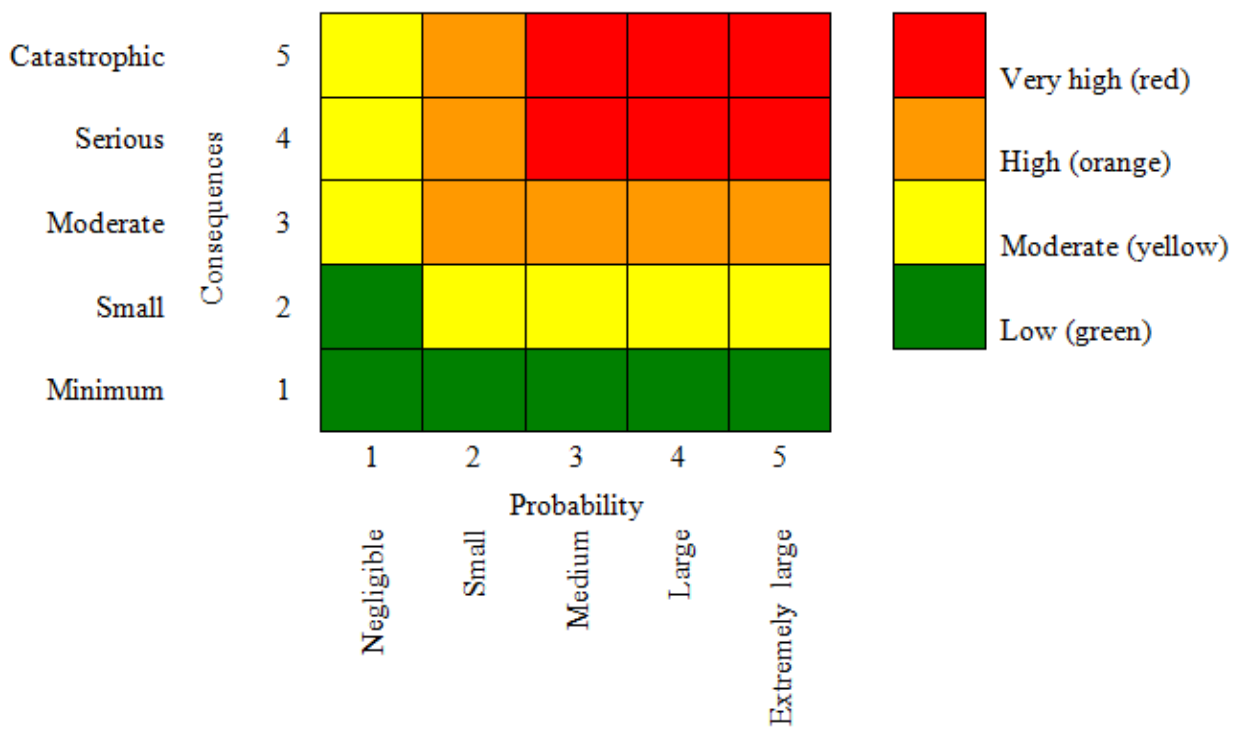

3.6. Determination of the combination of the risk - multi risk

Multi risk is a combination of two or more potential dangers, if they:

1. Occur at the same time or if they occur consecutively;

2. Depend on each other, or if they are caused by the same event or event initiator/trigger;

3. Pose a threat to the same elements (vulnerable/exposed elements) without chronological coincidence. Simultaneous potential dangers are also called side-events, destructive effects, domino effects or the waterfall effect. 
3.7. Risk treatment

By treating unacceptable risks, i.e. taking various planned measures, the level of the risk is reduced to an acceptable level. Risk treatment, generally comprises of: a risk, activity, carrier of the activities, time of realization, associates in realizing the activities, time and manner of reporting.

3.8. Creation of the risk maps

For the purposes of the Assessment, risk maps are made. Risk maps are an important tool for displaying the risk in the whole area, for each risk, as well as for the overall risk. Maps facilitate the presentation of the results of the risk matrix and understanding of the level of the risk, as well as visualization of the status of the risk for the purposes of making adequate decisions.

\section{CONCULSION}

Risk management at the local level is crucial to addressing the challenges and represents the first level of management that takes measures in reducing the risk of disasters, prepares answers to future risks and responds to natural disasters. Therefore, the key issues concerning local government in the implementation of appropriate risk management of disasters are: local government capacity (knowledge, experience, authorization), the cooperation of citizens, private sector and local authorities, the level of involvement of vulnerable groups of citizens in decision-making activities and the formation of management policy and the level of participation of local governments in prevention planning and disaster risk reduction at the national level. In order to improve management, it is necessary to expand and improve local capacities by increasing knowledge, providing resources, establishing new institutions of good management and greater local autonomy levels. In Serbia, the most important problems of managing emergency situations were identified as personnel problems, lack of equipment and material and technical resources, insufficient investment in prevention, lack of money, poor state of public enterprises, insufficient involvement of local governments, lack of awareness and legal problems. Undeveloped state of institutions is noticeable because of the unclear decision-making procedures within the institutional system. Above all, the most significant problems in terms of managing the risks of natural disasters emphasizes ambiguous relationship between the national and local levels of government, as well as the lack of cooperation between the public, private sector and nonprofit organizations as one of the objectives of adaptive management.

The assessment of vulnerability, as the general document, provides answers to many questions related to the size of danger, method of response, size and positioning of the forces for a response, i.e. systematizes all potential subjects for a quick and proper response to an emergency situation.

Acknowledgement: The research presented in this paper was financed by the Ministry of Science and Technological Development of Serbia within the projects III 43014 and III 42006. 


\section{REFERENCES}

1. Boin, A., Ekengren, M., Rhinard, M. (2013). The European Union as Crisis Manager Patterns and Prospects, Cambridge University Press, Cambridge.

2. Guidelines on the Methodology for the preparation of vulnerability assessment of natural and other disasters and plans for protection and rescue in emergency situations ("Official Gazette of RS", no. 18/17).

3. Hollis, S. (2014). Irrational response to natural disasters: Explaining the global rise of regional disaster risk management, Phd dissertation, Hertie School of Governance, Berlin.

4. Kešetović, Ž. (2010). Crisis management as part of the security system of the Republic of Serbia, In: R. Gaćinović, Serbia - Building of national security, Institute for Political Studies, Belgrade, pp. 235-250. (in Serbian)

5. Law on emergency situations ("Official Gazette of RS", no. 111/09, 92/11 and 93/12).

6. Milašinović, S., Kešetović, Ž. (2009). Social changes and modern crises - challenge for theory and managerial practice, NBP - Journal of Criminalistics and Law, Vol. XIV No.1, pp. 117-132.

7. Regulation on the content and the method of preparing plans for protection and rescue in emergency situations ("Official Gazette of RS", no. 8/11).

8. Smith, K., Petley, D.N. (2008). Environmental hazards - Assessing risk and reducing disaster, Taylor\&Francis, New York.

9. Tercovich, G. (2014). Towards a Real Comprehensive Approach, Journal of Contingencies and Crisis Management, 22 (3), pp. 150-157.

10. The Hyogo Framework for Action 2005-2015: Building the Resilience of Nations and Communities to Disasters (HFA) - Extract from the final report of the World Conference on Disaster Reduction (A/CONF.206/6), United Nations Office for Disaster Risk Reduction (UNISDR), www.unisdr.org/we/coordinate/hfa

11. Van Westen, C.J., Alkema, D., Damen M.C.J., Kerle, N., Kingma, N.C. (2011). Multi-hazard risk assessment, Guide book, United Nations University - ITC School on Disaster Geoinformation Management, Twente.

\section{ULOGA LOKALNE SAMOUPRAVE U ZAŠTITI OD ELEMENTARNIH NEPOGODA I DRUGIH VIDOVA OPASNOSTI U SRBIJI}

Proces upravljanja vanrednim situacijama, počev od procesa procene rizika od elementarni nepogoda $i$ drugih opasnosti, preko preduzimanja mera prevencije, zaštite $i$ spasavanja, ublažavanja i obnove, ne treba posmatrati kao faktor opterećenja društva, već kao faktor razvoja. Opasnosti $i$ nesreće ne odnose samo ljudske žrtve, već nanose i ogromnu, često nenadoknadivu štetu koja slabi materijalnu moć države i pojedinaca, a može naneti i dugoročne probleme društvu u celini. U tom kontekstu, neophodno je da država utiče na smanjenje rizika i opasnosti, povećava značaj $i$ efikasnost učešća resursa $i$ kapaciteta angažovanih u procesu upravljanja $u$ vanrednim situacijama, a time ujedno doprinosi i bezbednosti i razvoju društva u celini.

Ovaj rad bavi se probemom izrade procene ugroženosti od elementarnih nepogoda kao jednog od zadataka lokalne samouprave u upravljanju vanrednim situacijama. Nakon urađene procene se na osnovu nivoa rizika u lokalnoj zajedici mora sagledati i sa kakvim raspoloživim kapacitetom kako tehničkim tako i ljudskim raspolaže lokalna zajednica, $i$ da se na osnovu činjeničnog stanja u skladu sa zakonom urade i planovi za zaštitu i spasavanje.

Ključne reči: elementarna nepogoda, rizik, procena ugroženosti, procena rizika, lokalna samouprava 